\title{
Motivations to be School Teacher: an Examination of Student Teachers' Reasons
}

\author{
Ainur Rosyid \\ College of Education, Esa Unggul University, Jakarta, Indonesia \\ Corresponding e-mail: ainur.rosyid@esaunggul.ac.id
}

\begin{abstract}
The research aimed to deeply explore what motivated the students to be teachers and to examine whether or not any differences of motives between male and female students. The research used quantitative approach, using questionnaire adapted from Factors Influencing Teaching Choice (FIT-Choice) scale and employed Likert scale. Primary data of the research was student motivation to be a teacher. The number of student being respondents was 83 students. Data collected was analysed using mean or percentage and independent sample t-test. The research results showed the motives of students being a teacher as follows: make social contribution (mean: 5,66), enhance social equity (mean: 5,54), shape the future of children (mean:5,51), work with children (mean:5,29), prior teaching and learning experience (mean:5,27), intrinsic value (mean:5.16), job security (mean: 4,79), perceived teaching abilities (mean: 4,78), time for family (mean: 4,76), and social influences (mean: 4,39). However, there were five dominant motives spread along the aspects: wanting to help children learn, influencing the next generation, raising the ambitions of underprivileged youth, making social contribution, and being interested in teaching. The independent sample t-test analysis resulted that there is no difference of motivation between male and female students of Elementary Teacher Education, but one motive, time for family, where the $\mathrm{P}$ value $(0,02)$ is smaller than 0,05 . The research recommends recruiting high school students with high social sense to be student teacher in college of education.
\end{abstract}

Keywords: motives being a teacher, FIT-choice, motivation

\section{INTRODUCTION}

Choosing a department in a university can be a start for many high school leavers in choosing a career. Padaguri (2011) mentioned that choosing a career is difficult task. Challenges in choosing a career plan may also result in settling for career never planned for.

This happened to a senior student of computer science came and asked me the tuition fee of teacher education department per semester. She said that she wants to be a teacher. She should be expected to be a computer scientist rather than expected to be a teacher. The occurrence triggered me to question what motivates the student to be a teacher. Teacher is not a most-wanted profession in Indonesia. A study conducted in University of California, in 2013 pointed out that the most-wanted professions in the next 10 years are software application developer, market analyst, biomedical engineer, accountant or auditor, network and computer system administrator, petroleum geologist, child day nursery, elderly specialist, and environment specialist. Indeed, teacher is the last option of career choice chosen by people when they desperately look for a job that, for them, is better than teacher (Klassen, 2011).

However, the number of students in teacher education faculty, Esa Unggul University, increased in the last two years. It means more people want to be a teacher. What motivates them to be a teacher leaves a question. Being a teacher should not be taken as a career for those who cannot be accommodated in other jobs (Maphosa, 2014).

Many studies have been conducted to examine what attracts people into teaching jobs. Enjoying the subjects they would teach and liking to work with children are some of the reasons for choosing 
teaching jobs (Kyriacou, Hultgren, \& Stephens, 1999). Watt, Richardson, Klusmann, Kunter, Beyer, Trautwein, and Baumert, (2012) conducted a study and revealed the factors highly influencing teaching include intrinsic value, perceived teaching ability, the desire to make a social contribution, to work with children, and have had positive prior teaching and learning experiences. However, those studies were not specific in primary education teacher.

A study conducted by Agustien (2010) revealed that motivations of being teachers in a special need school are fundamental needs: primary and secondary needs fulfilment. In addition, the salary remunerated to the rate of Regional Minimum Wages is the other factor that motivates them. Besides, the teachers felt they suited to their abilities. The study sampled in special need school teacher, especially women teacher.

Being a teacher in Indonesia is not a faverable job, especially primary education teacher. The status of being primary teacher is perceived the lowest position in hierarchy of teacher education. However, the increasing number of students in primary teacher education, Esa Unggul University indicates that they have their own reasons for choosing primary education teacher as their career path to be.

This study examined the reasons of student teacher in primary teacher education program at Esa Unggul for choosing teacher as their career. Also, the study examine whether or not the different reasons of being teacher between male and female student teacher.

It is important to examine the reasons why they choose to be a teacher in their first options. Those reasons could be potentially incorporated into education programs in department through coursework and practice.

\section{LITERATURE REVIEW}

\subsection{Theory of Motivation}

Motivation is defined as a driving force (AM Sardiman, 2007), energy (Mc Donald in AM Sardiman, 2009) and a stimulus (Purwanto, 2007) makes a person to do something, makes a person change in order to reach a goal.

Sardiman (2009: 89-91) mentioned two kinds of motivations: intrinsic and extrinsic motivation. Intrinsic motivation comes from the internal reasons of a person. While extrinsic motivation comes from external reasons of the persons (environment).
Basically, people do activities to fulfil their needs: biological, psychological or spiritual needs.

\subsection{Maslow's Theory}

Maslow's theory of motivation is known as hierarchy of needs theory and commonly used for human motive classification. The theory is based on internalised needs. The theory has four principles: first, behaviour changes because of an unsatisfied need, satisfied needs are not a motivator, second, individuals arrange their need based on the priority of importance, third, when the needs are fulfilled in one level, it will advance to the next level of needs, and four, unmaintained satisfaction needs will become a priority need again.

Maslow (1954) classified human motives into five levels:

1) Physiological needs - the fundamental needs for biological satisfaction such as food, shelter, clothing, sleep, sex, etc.

2) Safety needs - the need to avoid physical harm and uncertainty about one's well-being such as threat, deprivation, danger, etc.

3) Social needs - the need to be accepted by people or society such as friendship, giving and receiving of love, etc.

4) Esteem needs or self-esteem needs, ego needs (Pardee, 1990) - the need to feel important, to be admired, and worthwhile such as recognition, status

5) Self-actualization or self-realization need - the need to get the maximum rewards from one's life experience to maximize skills, abilities, and potentials

Martin and Joomis (2007) mentioned Maslow's theory basically categorised the motives into two themes: deficiency needs and growth needs.

Deficiency needs is the fundamental and essential needs for a person's well-being. The needs include physiological needs, safety and security needs, love and belongingness needs, self-worth and self-esteem needs. While the growth needs means that when the more the needs are satisfied, the more people want to pursue them.

\subsection{Expectancy-Value Theory}

Expectancy - value theory is one of the cognitive theories of motivation. Cognitive theory of motivation focuses on beliefs, expectations, and the needs for order, predictability, and understanding. In expectancy - value theory, people are motivated to do an activity or task to the extent that they expect to 
succeed times the value they place on the success (Wigfield \& Eccles, 2000).

The theory concerns with expectancy for success and task value. The expectancy for success is influenced by two factors: perception of task difficulty and self-schemas. Perception of task difficulty obviously impacts the expectancy for success. When people perceive a task as extremely difficult, they are less likely to expect success. Selfschemas also influence the expectancy for success, including self-concepts and sets of beliefs about the kind of person believe to be (Eggen, 2007).

The other concern of expectancy-value motivation is task value. Factors influencing task value are intrinsic interest, importance, utility value, and cost. Intrinsic interest points the characteristics of job or profession that induce persons eager to involve in it. Importance is the extent to which a job allows people to confirm or disconfirm important aspects of their self-schemas. For example, if a person believes he is a good teacher, doing well in teaching will be important to him. He confirms his belief about his ability. Utility value is another factor influencing task value. It is a perception of usefulness of the activity for meeting the future goals, including career goals. The last factor influencing task value is cost. Cost means resources invested in doing tasks. The cost is not only about money, but also about time, energy and emotion (Enggen, 2007).

\subsection{Motivation to be a teacher in Indonesia}

Indonesian students in senior high schools see teaching is a not favourable job. They think that being teacher will not give them any opportunity to be a leader, earn more money and power. In addition, Tempo released top ten departments that students are interested at most: Information Technic, Public Health, Pharmacy, and Computer Science (Tempo, 2015).

Kyriacou (1998) concluded that there are three main reasons for choosing a career in teaching. First, altruistic reasons are dealing with seeing teaching as a socially worthwhile and important job, a desire to help children succeed, and a desire to help society improve. Second, intrinsic reasons are the motives dealing with aspects of the job activity itself, such as the activity of teaching children, and interest in using their subject matter knowledge and expertise. Third, extrinsic reasons deal with aspects of the job that not in the work itself, such as long holidays, level of pay and status.

\section{METHODOLOGY}

This research was conducted in Esa Unggul University, Jakarta. The researcher used quantitative approach, using questionnaire adapted from Factors Influencing Teaching Choice (FIT-Choice) Scale with Likert scale from 1 (extremely not important) to 7 (Extremely important). Watt and Richardson (2006) modelled a comprehensive scale to measure factors influencing teaching which is known as FITChoice Scale. The scale is heavily relying on the expectancy-value theory. The scale model accommodates the altruistic motivations, personal reasons, intrinsic motivations, and ability related beliefs. Besides, it taps individual perceptions about teaching profession (Watt, Richardson, Klusmann, Kunter, Beyer, Trautwein, Baumert: 2012).

While adapting the instrument, for the purpose of this study and contextual reasons, some items were left out. For instance, the factor of job transferability "teaching will be a useful job for me when travelling' was excluded since they are not applicable in the context of Indonesian culture.

Primary data of the research was student motivation to be a teacher. The number of student being respondents was 83 students (Male: 13 and Female: 70). Data was collected by distributing questionnaire, and analysed using mean or percentage. Independent sample t-test was applied to analyse the different motivation between male and female students.

\section{RESULTS AND DISCUSSION}

The validity value of the questionnaire was from 0,213 to 0,690 (>0,207), by using Pearson Product Moment analysis. The questionnaire used in the research was valid. The reliability test using Alpha Cronbach with the value of 0,7463 resulted in high category which meant that the questionnaire was reliable.

\subsection{Motivations to Be a Teacher}

Teaching or being a teacher is a very important profession building and shaping the future of children. People interested in teaching profession should not only help the students in learning, but also become a model for them (Maphosa: 2014). So, teaching should not be taken as career for those who cannot be accepted in other careers.

The questionnaire result of this study can be seen in table 1. 
Table 1 Mean of the Motivation Factors

\begin{tabular}{lll}
\hline Motivation & Mean & SD \\
\hline $\begin{array}{l}\text { Perceived } \\
\text { Teaching }\end{array}$ & 4.78 & 1.08 \\
$\begin{array}{l}\text { Abilities } \\
\text { Intrinsic Value }\end{array}$ & 5.16 & \\
$\begin{array}{l}\text { Job Security } \\
\text { Time for Family }\end{array}$ & 4.79 & 1 \\
$\begin{array}{l}\text { Shape the } \\
\text { Future of }\end{array}$ & 5.51 & 1.18 \\
$\begin{array}{l}\text { Children } \\
\text { Enhance Social }\end{array}$ & 5.54 & 1.34 \\
$\begin{array}{l}\text { Equity } \\
\text { Make Social }\end{array}$ & 5.66 & 1.21 \\
$\begin{array}{l}\text { Contribution } \\
\text { Work with }\end{array}$ & 5.29 & 1.02 \\
$\begin{array}{l}\text { Children } \\
\text { Prior Teaching } \\
\text { and Learning }\end{array}$ & 5.27 & 0.94 \\
$\begin{array}{l}\text { Experiences } \\
\text { Social }\end{array}$ & & 1.2 \\
Influences & 4.39 & 1.1 \\
\hline
\end{tabular}

The findings from this study were important that they indicated that the student teachers of Esa Unggul University had different motivations to be teachers from other countries. This study revealed that the motivation of students to be teacher was to make social contribution (mean: 5.66). This motivation could be classified as altruistic reasons, the reasons deal with seeing teaching as a socially worthwhile and important job, a desire to help children succeed, and desire to help society improve (Chuene, Lubben, \& Newson, 1999). Based on the mean, the motivations orderly rated were aspect of enhancing social equity (5.54), shaping the future of children / adolescent (5.51), working with children / adolescent (5.29), prior teaching and learning experiences (5.27), intrinsic value (5.16), job security (4.79), perceived teaching ability (4.78), time for family (4.76), and social influences (4.39).

Yet, highly rated motivations to be a teacher were orderly to work with children / adolescents, enhance social equity, to make social contribution, and intrinsic value. "I want to help children and adolescent learn", "teaching will allow me to influence the next generation", "Teaching will allow me to raise the ambitions of underprivileged youth", "Teaching allow me to provide a service to society" and "I am interested in teaching" are the reasons of student teachers of Esa Unggul University to be teachers. Different from this study, Watt, Richardson, Klusmann, Kunter, Beyer, Trautwein, and Baumert, (2012) conducted a study and revealed the factors highly influencing teaching includes consistently intrinsic value, perceived teaching ability, the desire to make a social contribution, to work with children, and have positive prior teaching and learning experiences.

While, the low rated motivation for choosing to be a teacher was social influences, especially friends. No one of the student teachers in Esa Unggul University was encouraged by their friends. It is also stated by Topkaya and Uztosun (2012) in their study that friends' power was less influential factor for person to be a teacher. However, the support of family, "my family think I should become a teacher" became one of the highly rated reasons to be a teacher. As stated by Richardson and Watt (2005), family played an important role to pull person into teaching job as a career change.

\subsection{Motivations to be a Teacher by Gender}

Using Independent Sample t Test with assuming equal variances and the significant $5 \%$ differentiated the motivations between male and female students. The results can be seen in table 2 .

Table 2 Motivations by Gender

\begin{tabular}{lcc}
\hline \multirow{2}{*}{ Motivation } & \multicolumn{2}{c}{ Mean } \\
\cline { 2 - 3 } & M & F \\
\hline Perceived Teaching & 14.61 & 14.27 \\
Abilities & & \\
Intrinsic Value & 15.38 & 15.5 \\
Job Security & 14.92 & 14.27 \\
Time for Family & 17.92 & 19.21 \\
Shape the Future of & 17.23 & 16.38 \\
Children & & \\
Enhance Social Equity & 16.38 & 16.67 \\
Make Social Contribution & 5.84 & 5.62 \\
Work with Children & 21.15 & 21.3 \\
Prior Teaching and & 10.30 & 10.57 \\
Learning Experiences & & \\
Social Influences & 12.76 & 13.25 \\
\hline
\end{tabular}

This study also revealed different motivations between male and female students. The study generally showed that there was no different motivation to be a teacher between male and female students based on the analysis of independent sample t test. However, the only factor or motivation that differentiates between from male and female student is time for family, where $\mathrm{P}$ value $(0,02)$ is smaller than 0,05. Besides, female students tend to rate highly on time for family than male students (mean female: 19.21, male: 17.92). Different from this result, Watt, Richardson, Klusmann, Kunter, Beyer, Trautwein, and Baumert, (2012) stated in 
their study that family time is less influential factor for person to be a teacher. Another highly interesting finding is that male students rated highly on shaping the future of children than female students (mean male: 17.23, female: 16.38). However, based on the analysis of independent sample $t$ test it showed that there was no difference between male and female student on shaping the future of children or adolescent.

\section{CONCLUSION}

The FIT-Choice scale has displayed good validity and reliability across the sample. The motivations of student being a teaching are orderly aspect of making social contribution, enhancing social equity, shaping the future of children / adolescent, working with children/adolescent, prior teaching and learning experiences, intrinsic value, job security, perceived teaching ability, time for family, and social influences. However, if looking up more details, highly rated reasons to be teachers are orderly to help children and adolescent learn, to influence the next generation, to raise the ambitions of underprivileged youth, to make worthwhile social contribution, and interest in teaching. The lowest rated motivation to be a teacher is social influences, especially friend's influences. Based on the analysis of independent sample t test, there is only one reason, time for family, differentiates male from female student reasons being a teacher.

\section{ACKNOWLEDGEMENTS}

This research was financially supported by University of Esa Unggul.

\section{REFERENCES}

Agustien, N. (2010). Motivasi Menjadi Guru SLB. diakses 15 Februari 2016 http://www.gunadarma.ac.id/library/articles/gra duate/psychology/2010/Artikel_10505143.pdf

Chuene, K., Lubben, F. \& Newson, G. (1999). The Views of Pre-service and Novice Teachers on Mathematics Teaching in South Africa Related to Their Educational Experience, Educational Research, Vol. 41

Eggen, P., Kauchak, D. 2007. Educational Psychology: Windows on Classrooms. New Jersey, USA: Pearson

Klassen, R.M., Al-Dharfi, S, Hannok, W. \& Betts, SM. 2011. Investigating pre-service teacher motivation accros cultures using the Teacher's Ten Statement Test, Teaching and Teacher Education, 27.3.

Kyriacou, C., Kobori, M. 1998. Motivation to Learn and Teach English in Slovenia, Educational Studies, 24, 23-34

Kyriacou, C., Hultgren, A., \& Stephens, P. 1999. Student Teachers' Motivation to Become a Secondary School Teacher in England and Norway. Teacher Development. 3.3. 373

Maphosa, C., Bhebhe, S., Shumba, J.,. 2004. What Motivated Them to Become Teachers? An Examination of Trainee Teachers' Motives of Training as Teachers. Mediterranean Journal of Social Sciences, 5.7, 483

Martin, D. \& Joomis, K. 2007. Building Teachers: A Constructivist Approach to Introducing Education. Belmont, CA: Wadsworth. pp 72-75

Maslow, Abraham H. 1954. Motivation and Personality. New York: Harper and Bros.

Padaguri, V.G., (2011). Case Study: Job Selection and Career Planning: unwinding the dilemma. Journal of Contemporary Research in Management pp 1-12

Pardee, R.L. 1990. Motivation Theories of Maslow, Herzberg, McGregor \&McCelland. ERIC

Purwanto, M. Ngalim. 2007. Psikologi Pendidikan. Bandung: PT Remaja. Rosdakarya

Richardson, P.W., Watt, H.M.G. 2005. I've Decided to Become a Teacher: Influences on Career Change. Teaching and Teacher Education. 21. 475-489

Richardson, P.W., Watt, H.M.G. 2006. Who chooses Teaching and why? Profiling Characteriscs and Motivations across three Australian universities, Asia-Pacific Journal of Teacher Education, 34.1, 27-56

Sardiman, A.M. 2009. Interaksi dan Motivasi Balajar Mengajar. Jakarta: Rajawali Press

Surya, A. 2014. Pak Guru. Jakarta: Ersa

Topkaya. E.Z., Uztosun, M.S. 2012. Choosing Teaching as a Career: Motivations of Preservice English Teachers in Turkey. Journal of Language Teaching and Research. 3.1. 132

Watt, HMG., Richardson, PW., Klusmann, U., Kunter, M., Beyer, B., Trautwein, U., \& Baumert, J., 2012. Motivations for Choosing Teaching as a Career: An International Comparison using the FIT-Choice Scale. Teacher and Teacher Education. Elsevier. 792

Wigfield, A. \& Eccles, J.S. 2000.Expectancy Value Theory of Achievement Motivation. Contemporary Educational Psychology, 25, 68-81 
https://m.tempo.co/read/news/2015/05/11/07966519

5/inilah-daftar-jurusan-paling-diminati-

pendaftar-snmptn diakses 15 Februari 2016

(http://www.vistaeducation.com/news/v/all/prediksi-

pekerjaan-paling-dicari-10-tahun-kedepan)

diakses 15 Februari 2016 